Ann. Biol. anim. Bioch. Biophys., 1977, 17 (6), 961-969.

\title{
Functional compensatory hypertrophy resulting from spontaneous or induced atrophy disconnecting one of the ovaries of Triatoma infestans (Heteroptera, Reduviidae, Triatominae)
}

par Leda REGIS*

Equipe 24 de Neuroendocrinologie des Insectes, C. N. R. S. Université Pierre et Marie Curie,

12, rue Cuvier, 75230 Paris Cedex 05, France.

Summary. The presence of the upper part of the mesodermic oviduct in Triatoma infestans was necessary during the pre-imaginal molt so that the adjacent ovary could assure vitellogenesis. If this part was excised after imaginal molt, the ovary functioned normally.

Spontaneous (3.5 p. 100 of females) or induced suppression of this part of the oviduct before the end of the 5th larval molt caused a compensatory reaction in the contralateral ovary.

If the females were well fed, a double number of eggs was produced by the functional ovary and the blood content per egg produced was the same as the normal female having two functional ovaries.

The number of eggs produced in Triatoma infestans is proportional to the amount of blood ingested (Regis, $1977 a, b$ ) ; one egg can be formed with $16.6 \mathrm{mg}$ blood. We have observed females with only one functional ovary; the other, although present, being atrophied. This abnormality, similar to that described in another Hemiptera, Dysdercus (Pluot, 1973), was associated with a regression of the upper part of the lateral oviduct which is of mesodermic origin.

The percentage of Triatoma infestans females presenting this spontaneous abnormality is low (14/400). We attempted to obtain the abnormality regularly by sectioning the oviduct before the end of instar 5, causing regression of the upper part.

This operation being successful, we wished to determine if the remaining functional ovary was hypertrophied, leading to the same egg production for the same amount of blood ingested as in the normal female.

* Present address : Departamento de Biologia general Universidad Federal de Pernambuco 50.000 RECIFE (PE), Brésil. 


\section{Material and methods.}

Rearing conditions. The insects were kept in the dark at $28^{\circ} \mathrm{C}$ with 70 to 80 p. 100 relative humidity. The females used for fertility studies were reared individually from imaginal molt. They fed from guinea-pigs every 3-4 days for one month (8 times). The weight of the blood ingested was estimated for each female at every meal by weighing before and after blood intake. A 1-month old male having ingested at least 3 meals was presented to the female before egg laying.

Operation. The operation was done by cutting the oviduct or hemicastrating the animal two days after the beginning of instar 5, when the junction of the ectodermic and mesodermic anlages of the oviduct had not yet occured, and the larval intestine contained little blood. Adults were operated 1 day after the imaginal molt. The oviduct was always severed at its mesodermic part near the ovary. The conscious animal was fixed in a dissection basin containing Ringer solution. The oviduct was cut or the

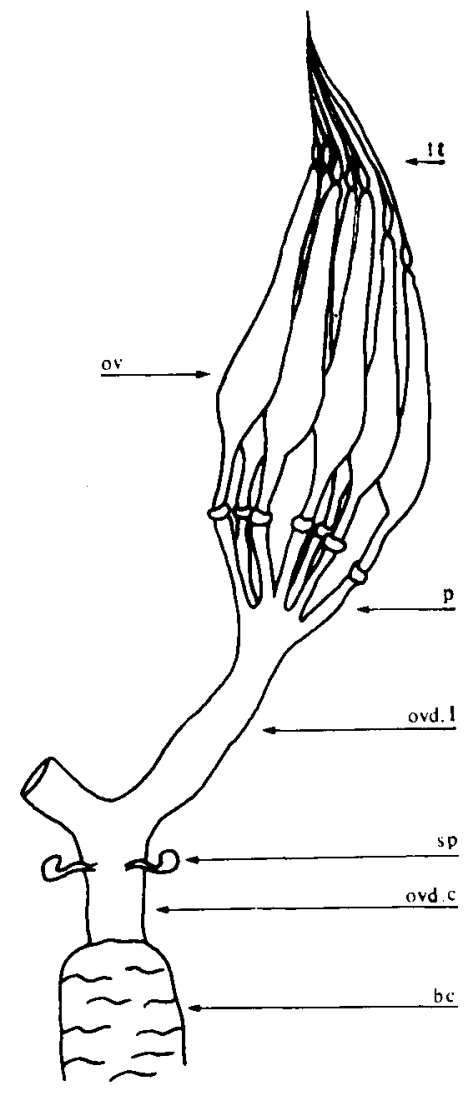

FIG. 1. - Diagram of the female genital apparatus

$\mathrm{ft}=$ terminal filament ; ov $=$ ovarioles ; ovd. $\mathrm{l} .=$ lateral oviduct ; $\mathrm{p}=$ pedicel ; ovd. $c$. $=$ common oviduct $; b c=$ bursa copulatrix. 
ovary removed through a small incision practised in the abdominal dorsal cuticle, thus avoiding injury to the other organs. The incision rapidly closed by itself. The insects could be fed 2 days after the operation as the cuticle was already well-healed and withstood the pressure of the distended abdomen following a blood meal (an instar 5 larva can ingest up to 11 times more blood than its body weight). Operated animals had a 72 p. 100 survival rate.

Examination of ovaries. Ovaries in most cases could be examined fresh after the envelope of the ovariole was removed. They were then transparent and could be observed under the microscope. Ovaries were fixed in Bouin, sectioned and then stained in Heidenhain's azan.

\section{Results.}

\section{Genital apparatus and ovary development.}

The ovary is composed of 7 acrotrophic or telotrophic-type ovarioles since the nurse cells remain in the germarium. The 7 ovarioles join, forming a short, thick lateral oviduct in the adult. The two lateral oviducts unite at the base to form the common oviduct which ends in the bursa copulatrix. The two spermathecae are inserted by a short canal in the anterior part of the common oviduct (fig. 1).

At the beginning of instar 5 , the ovary is very small, the lateral oviduct is much longer and smaller than that of the adult (fig. $2 a, 2 b$ ), and the ecto and mesodermic anlages of the oviduct touch but the junction of their lumen is only effected at the end of the instar. During this instar, meiosis appeared in all ovarioles between days 5 and 10 after intake of the blood meal. At the imaginal molt, occuring about day 19 after this intake, germarium tissues were differentiated; the trophic core formed and several growing oocytes were observed in all ovarioles. The first follicle formed around the oocyte having the most advanced growth. Enclosed in prefollicular cells, the oocytes descended from the germarium one by one into the vitellarium, where they accomplished vitellogenesis.

\section{Results of disconnecting gonads from the genital routes.}

Disconnecting the lateral oviduct near the ovary at instar 5 caused regression of all the part of the oviduct which was mesodermic in origin. The genital apparatus of operated animals was identical to that of abnormals (fig. $2 c$ ). As in the spontaneous abnormality, the ovary severed from the genital routes at imaginal molt retained its instar 5 state and size. It was smaller than the normal ovary and its size did not vary with age and the physiological state of the female (fig. 3).

Histological examination of atrophied ovaries showed that severing the oviduct did not prevent gonial mitoses and achievement of meiotic prophase. At first, oocytes grew normally, but degenerated at the beginning of previtellogenesis. They were no longer than $400 \mu \mathrm{m}$, while in a normal ovary, the oocytes are $700 \mu \mathrm{m}$ long at the end of previtellogenesis.

Structural changes were also observed, such as a very high number of pyknotic nuclei in the germarium; this number was also high in the trophic core where cells 

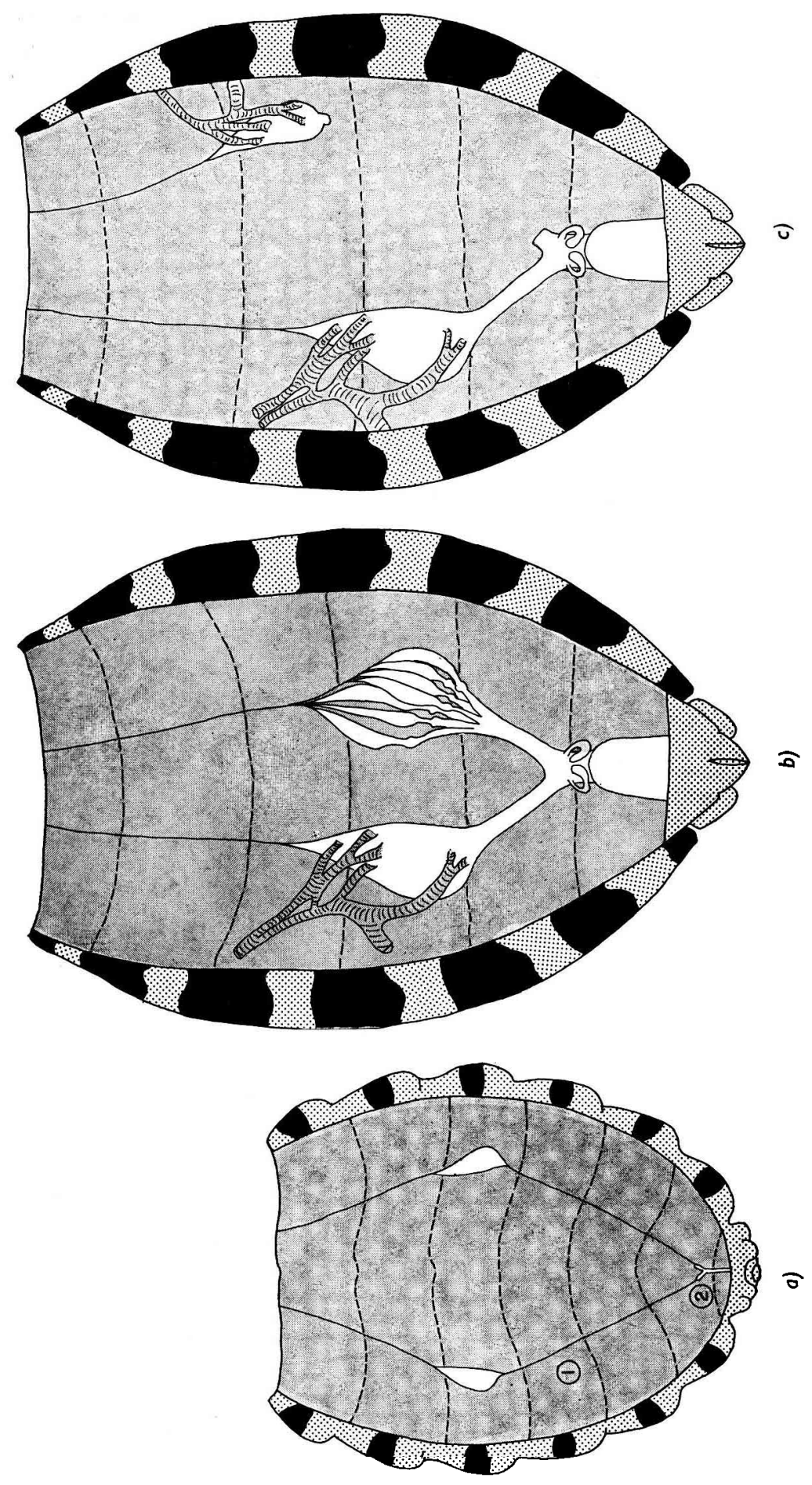

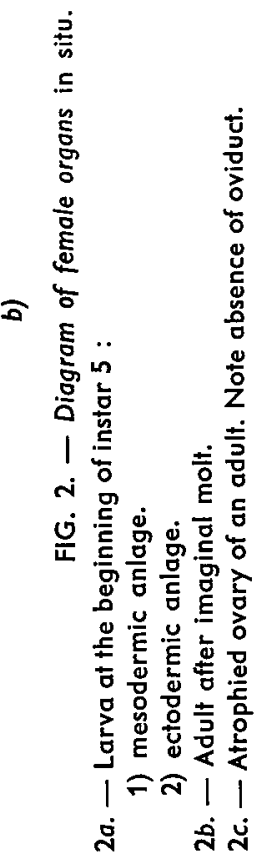


were rarely found in the normal ovary. The trophic cord joining each oocyte to the trophic core was very small and did not appear normal. Structural changes were very clear in the pedicel ; the lumen of this organ never formed. These modifications were identical to those reported in Dysdercus (Pluot, 1973).

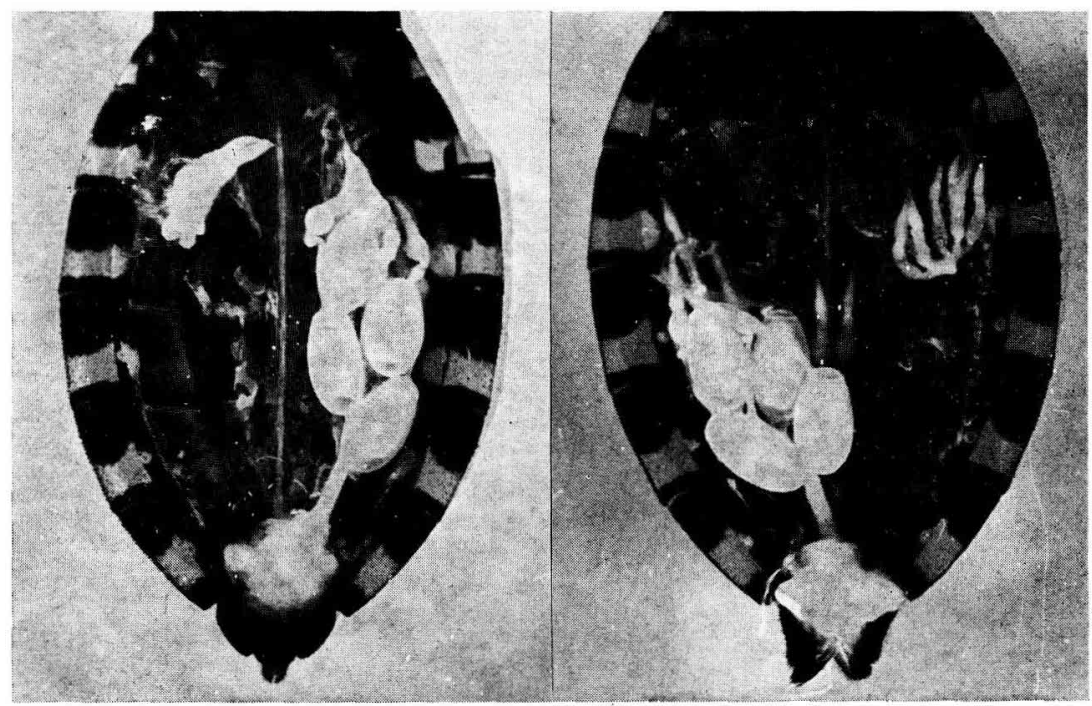

FIG. 3. - Adults with an atrophied ovary. The normal ovary has 4 chorionated eggs.

The normal functioning of the ovary was inhibited by the absence of gonad-genital pathway communication, whether spontaneous or experimentally induced before the ecto and mesodermic anlages of the oviduct joined. On the other hand, if the oviduct was sectioned after imaginal molt, following the junction of the anlages, the ovary continued to function normally.

TABLE 1

Egg production in females having an atrophied ovary

\begin{tabular}{|c|c|c|c|c|c|}
\hline & \multirow{2}{*}{$\begin{array}{c}\text { Female } \\
n^{0}\end{array}$} & \multicolumn{2}{|r|}{ Meal } & \multirow{2}{*}{$\begin{array}{c}\text { Number of eggs } \\
\text { produced }\end{array}$} & \multirow{2}{*}{$\begin{array}{l}\text { Blood/egg } \\
\text { (mg) }\end{array}$} \\
\hline & & Number & $\begin{array}{l}\text { Blood intake } \\
(\mathrm{mg})\end{array}$ & & \\
\hline $\begin{array}{l}\text { Spontaneous } \\
\text { abnormality }\end{array}$ & $\begin{array}{l}1 \\
2 \\
3\end{array}$ & $\begin{array}{l}8 \\
8 \\
8\end{array}$ & $\begin{array}{l}1,160 \\
1,180 \\
1,090\end{array}$ & $\begin{array}{l}74 \\
75 \\
72\end{array}$ & $\begin{array}{l}15.67 \\
15,73 \\
15,18\end{array}$ \\
\hline $\begin{array}{l}\text { Experimental } \\
\text { abnormality }\end{array}$ & $\begin{array}{r}43 \\
86 \\
44 \\
100 \\
41\end{array}$ & $\begin{array}{l}8 \\
8 \\
8 \\
8 \\
8\end{array}$ & $\begin{array}{r}920 \\
1,200 \\
1,220 \\
1,220 \\
1,300\end{array}$ & $\begin{array}{l}44 \\
72 \\
80 \\
62 \\
98\end{array}$ & $\begin{array}{l}20,9 \\
16.67 \\
15,24 \\
20,34 \\
13,26\end{array}$ \\
\hline Mean & & & $1,161.25 \pm 120$ & $71.87 \pm 14.5$ & $16.62 \pm 2.48$ \\
\hline
\end{tabular}


Fertility.

The number of eggs depending on the quantity of blood ingested, the fertility of Triatoma infestans females is defined by the amount of blood necessary for forming one egg (Regis, 1977).

\section{- Fertility in females with a reduced number of ovarioles.}

The atrophied ovary may be seen immediately after imaginal molt due to the transparent cuticle which is still not tanned. We thus studied the fertility of 3 females with a spontaneous unilateral abnormality and that of females with an experimental ovarian abnormality. These females, having only one functional ovary, were intensively fed and their egg. laying observed over a long enough period to determine that fertility was not impaired (table 1). The amount of blood ingested and the ratio blood intake/egg produced was the same as that for normal females raised in identical conditions. This was also the case of animals hemiovariectomized either at instar 5 or after imaginal molt (table 2). The ratio blood intake/egg produced was the same in all cases, thus confirming compensatory regulation (egg production intensified in the remaining ovary) when one ovary was absent or non-functional.

TABLE 2

Egg production in females having only one ovary (unilateral ovariectomy)

\begin{tabular}{|c|c|c|c|c|}
\hline & $\begin{array}{c}\text { Female } \\
n^{\circ}\end{array}$ & $\begin{array}{l}\text { Blood intake } \\
(\mathrm{mg})\end{array}$ & $\begin{array}{c}\text { Number of eggs } \\
\text { produced }\end{array}$ & $\begin{array}{l}\text { Blood/egg } \\
(\mathrm{mg})\end{array}$ \\
\hline $\begin{array}{l}\text { Operated after } \\
\text { imaginal molt }\end{array}$ & $\begin{array}{l}47 \\
56 \\
97 \\
53 \\
96 \\
95 \\
99 \\
98\end{array}$ & $\begin{array}{r}690 \\
920 \\
990 \\
1,000 \\
1,020 \\
1,030 \\
1,110 \\
1,210\end{array}$ & $\begin{array}{l}39 \\
53 \\
59 \\
43 \\
65 \\
68 \\
73 \\
76\end{array}$ & $\begin{array}{l}17.69 \\
17.35 \\
16.78 \\
23.20 \\
15.69 \\
15.14 \\
15.20 \\
15.92\end{array}$ \\
\hline $\begin{array}{l}\text { Operated during } \\
\text { instar } 5\end{array}$ & $\begin{array}{l}150 \\
153 \\
135 \\
151 \\
152 \\
148 \\
102\end{array}$ & $\begin{array}{r}680 \\
720 \\
930 \\
1,020 \\
1,050 \\
1,090 \\
1,190\end{array}$ & $\begin{array}{l}35 \\
36 \\
52 \\
62 \\
63 \\
73 \\
59\end{array}$ & $\begin{array}{l}19.43 \\
20.00 \\
17.88 \\
16.45 \\
16.66 \\
14.93 \\
20.17\end{array}$ \\
\hline Mean & & $976 \pm 162.9$ & $57.07 \pm 13.2$ & $17.5 \pm 2.29$ \\
\hline
\end{tabular}

- Fertility in females with the oviduct sectioned after imaginal molt.

We wished to determine if late disconnection of the oviduct, no longer followed by regression, would disturb the functioning of the adjacent ovary. The eggs produced were retained in the ovaries and genital pathways, but all females produced about the same number, and sometimes a number identical to that produced by the other 
ovary (table 3). The fact that the ratio blood intake/egg produced did not differ significantly from that noted in normal females showed that sectioning the lateral oviduct after imaginal molt did nol affect ovary functioning.

TABLE 3

Egg production in females having uniloteral refention induced by oviduct disconnection ofter imoginal molt.

\begin{tabular}{cccccc}
\hline \multirow{2}{*}{$\begin{array}{c}\text { Female } \\
n^{\circ}\end{array}$} & Number & $\begin{array}{c}\text { Blood intake } \\
(\mathrm{mg})\end{array}$ & $\begin{array}{c}\text { Normal ovary } \\
\text { (eggs layed) }\end{array}$ & $\begin{array}{c}\text { Disconnected ovary } \\
\text { (eggs retained) }\end{array}$ & $\begin{array}{c}\text { Blood/egg } \\
(\mathrm{mg})\end{array}$ \\
\cline { 2 - 6 } & & & & & \\
\hline 94 & 3 & 480 & 16 & 17 & 14.5 \\
93 & 5 & 760 & 27 & 27 & 14.0 \\
83 & 7 & 840 & 18 & 17 & 24.0 \\
92 & 8 & 980 & 31 & 31 & 15.8 \\
90 & 7 & 1,030 & 39 & 32 & 14.5 \\
80 & 8 & 1,060 & 29 & 28 & 17.5 \\
91 & 8 & 1,070 & 29 & 32 & 13.5 \\
88 & 7 & 1,100 & 42 & 39 & 14.7 \\
87 & 8 & 1,100 & 41 & 31 & $15.99 \pm 2.85$ \\
89 & 8 & 1,150 & 40 & 38 & \\
\hline Mean & 6.9 & $957.0 \pm 197.0$ & $31.6 \pm 7.91$ & $30.2 \pm 7.3$ & \\
\hline
\end{tabular}

\section{Discussion.}

In all cases of spontaneous abnormality, the ovary disconnected from the genital routes could not assume vitellogenesis, and oocytes degenerated at the beginning of previtellogenesis. Sectioning the oviduct at the beginning of instar 5 caused regression of all parts of the oviduct of mesodermic origin and the ovary presented the same characteristics as in the spontaneous abnormality. Disconnected in this way, the ovary differentiated ; different regions of it formed, but structural changes were observed. These alterations, and especially those in the trophic core and nutritive cords, seemed responsible for the incapacity of these ovaries to insure oocyte growth. On the other hand, disconnection after imaginal molt had no effect on ovary functioning.

There are not many studies in the literature on the effect of the genital routes on the insect gonad. In Drosophila, testicle growth is impaired when the gonads and deferent canals are disconnected (Stern, 1941a, b; Bodenstein, 1946). However, in the same fly, grafted ovaries differentiate completely, independently of connection with the genital routes (Ephrussi and Beadle, 1935 ; Pantelouris, 1955). In Galleria mollonella also, larval grafted ovaries develop and produce ripe eggs (Allegret and Panon, 1969).

Studying the fertility of females with an ovary disconnected after imaginal molt, we observed that retention of chorionated eggs in the pedicels did not change the rhythm or intensity of vitellogenesis. This lack of regulation was also noted in Locusta migratoria by Joly (1964) and in Glossina fuscipes by N'Kouka (personal communication). However, in other insects in which the effect of egg retention on vitellogenesis 
has been studied, ripe eggs held in the genital apparatus had an inhibitory effect on ovary functioning (Musca domestica, Adams ef al., 1968 ; Adams, 1970 ; Iphita limbata, Nayar, 1958 ; Carausius morosus, Thomas, 1976 ; Rhodnius prolixus, Pratt and Davey, 1972 ; Huebner and Davey, 1973). In Rhodnius prolixus, a species akin to Triatoma infestans and also hematophagic, egg retention in the pedicels in virgin females caused the production of an antigonadotropin. This factor appeared to counteract the gonadotropic effect of the corpus allatum hormone, thus preventing vitellogenesis.

In our experiments, females were mated but most eggs were retained in the pedicels ; vitellogenesis, however, was not retarded.

These observations are difficult to reconcile ; they indicate a difference between the two species or that antigonadotropin was only produced in virgin females.

\section{Conclusion.}

In Triatoma infestans the oviduct, or at least the junction between the oviduct and the ovary during pre-imaginal instar, is necessary to the future good-functioning of the ovary. On the other hand, the ovary, separated from its oviduct after imaginal molt, produces eggs normally.

Anatomical or functional hemicastration does not diminish fertility ; a compensatory reaction doubles the production of eggs in the remaining ovary. Egg retention in the genital routes does not arrest egg formation or retard vitellogenesis.

Reçu en février 1977. Accepté en avril 1977.

Résumé. Chez Triatoma infestans la présence de la partie supérieure de l'oviducte d'origine mésodermique est nécessaire durant la mue préimaginale pour que l'ovaire adjacent assure ultérieurement la vitellogenèse. Si cette partie est enlevée après la mue imaginale, l'ovaire fonctionne normalement.

La suppression spontanée (chez 3,5 p. 100 des femelles) ou provoquée expérimentalement de cette partie de l'oviducte avant la fin de la $5^{\mathrm{e}}$ mue larvaire entraîne une réaction compensatrice de l'ovaire contralatéral. Si les femelles sont nourries abondamment, le nombre d'œufs produits par l'ovaire fonctionnel est double et la quantité de sang par cuf produit reste la même que chez la femelle normale possédant deux ovaires fonctionnels.

\section{References}

ADAMS T. S., ef al., 1968. Oostatic hormone production in houseflies Musca domestica with developing ovaries. J. Insect Physiol., 14, 983-993.

ADAMS T. S. 1970. Ovarian regulation of the corpus allatum in the housefly Musca domestica. J. Insect Physiol., 14, 349-360.

ALLEGRET P., PANON G., 1969. Essai d'étude quantitative du fonctionnement ovarien par la technique des greffes chez le Lépidoptère pyralide Galleria mellonella. C. R. Acad. Sc. Paris, 268, 397-400.

BODENSTEIN D., 1946. Developmental relations between genital ducts and gonads in Drosophila. Biol. Bull., 91, 288-294.

EPHRUSSI B., BEADLE G. W., 1935. La transplantation des ovaires chez la Drosophile. Bull. Biol. Fr. Belg., 69, 492-505. 
HUEBNER E., DAVEY K. G., 1973. An antigonadotropin from the ovaries of the insect Rhodnius prolixus Stal (Hem. Het., Reduviidae). Can. J. Zool., 51, 113-120.

JOLY L., 1964. Contrôle du fonctionnement ovarien chez Locusta migratoria (L.) I. - Effets de castrations totales et de ligatures unilatérales de l'oviducte. J. Insect Physiol., 10, 437-442.

NAYAR K. K., 1958. Studies on the neurosecretory system of Iphita limbata (Stal.). V. - Probable endocrine basis of oviposition in the female insect. Proc. Indian Acad. Sci., 47, 232-251.

PANTELOURIS E. M., 1955. Interactions between ovary and lateral oviduct in Drosophila melanogaster. J. Embryol. exp. Morph., 3, 86-91.

PLUOT D., 1973. Effets d'une discontinuité de l'oviducte sur l'ovaire et les pédicelles correspondants chez Dysdercus (Hem. Pyrrhocoridae). Ann . Soc. Ent. Fr. N. S., 9, 813-839.

PRATT G. E., DAVEY K. G., 1972. The corpus allatum and vitellogenesis in Rhodnius prolixus (Stal.). Il. The effet of starvation. J. exp. Biol., 51, 215-221.

REGIS L., 1977a. Nutrition ef fécondité chez Triatoma infestans (Heteroptera Reduviidae). Thèse $3^{\text {e }}$ cycle, Univ. P. et $M$. Curie, Paris, $91 \mathrm{pp}$.

REGIS L., 1977b. Le rôle du repas sanguin sur le rythme de ponte et la fécondité chez Triatoma infestans (Heteroptera, Reduviidae) (sous presse).

STERN C., 1941a. The growth of testes in Drosophila I. The relation between vas deferens and testis within various species J. exp. Zool., 87, 113-158.

STERN C., 1941 b. The growth of testes in Drosophila. II. The nature of interspecific difference. J. exp. Zool., 87, 159-180.

THOMAS A., 1976. La ponte de Carausius morosus $\mathrm{Br}$. ef son déferminisme neuro-endocrine. Thèse d'Etat, Univ. P. et M. Curie, Paris, pp. 147. 